\title{
Trophic versus geographic structure in stable isotope signatures of pelagic seabirds breeding in the northeast Atlantic
}

\author{
Jose Luis Roscales ${ }^{1,2, *}$, Elena Gómez-Díaz ${ }^{1,3}$, Verónica Neves ${ }^{4}$, Jacob González-Solís ${ }^{1}$ \\ ${ }^{1}$ Institut de Recerca de la Biodiversitat and Dept. Biologia Animal, Universitat de Barcelona, Av. Diagonal 645, \\ 08028 Barcelona, Spain \\ ${ }^{2}$ Dept. of Instrumental Analysis and Environmental Chemistry, Institute of Organic Chemistry, \\ Spanish National Research Council (CSIC), Juan de la Cierva 3, 28006 Madrid, Spain \\ ${ }^{3}$ Institute of Evolutionary Biology (CSIC-UPF), Passeig Maritim de la Barceloneta 37-49, 08003 Barcelona, Spain \\ ${ }^{4}$ Instituto do Mar, Cais de Santa Cruz, 9901-862 Horta, Açores, Portugal
}

\begin{abstract}
Feeding ecology and geographic location are 2 major factors influencing animal stable isotope signatures, but their relative contributions are poorly understood, which limits the usefulness of stable isotope analysis in the study of animal ecology. To improve our knowledge of the main sources of isotopic variability at sea, we determined $\delta^{15} \mathrm{~N}$ and $\delta^{13} \mathrm{C}$ signatures in the first primary feather of adult birds from 11 Procellariiform species $(\mathrm{n}=609)$ across 16 northeast Atlantic localities, from Cape Verde $\left(20^{\circ} \mathrm{N}\right)$ to Iceland $\left(60^{\circ} \mathrm{N}\right)$. Post-breeding areas (where the studied feather is thought to be grown) were determined using light-level geolocation for 6 of the 11 species. Isotopic variability was geographically unstructured within the mid-northeast Atlantic (Macaronesian archipelagos), but trophically structured according to species and regardless of the breeding location, presumably as a result of trophic segregation among species. Indeed, the interspecific isotopic overlap resulting from combining $\delta^{15} \mathrm{~N}$ and $\delta^{13} \mathrm{C}$ signatures of seabirds was low, which suggests that most species exploited exclusive trophic resources consistently across their geographic range. Species breeding in north temperate regions (Iceland, Scotland and Northern Ireland) showed enriched $\delta^{15} \mathrm{~N}$ compared to the same or similar species breeding in tropical and subtropical regions, suggesting some differences in baseline levels between these regions. The present study illustrates a noticeable trophic segregation of northeast Atlantic Procellariiformes. Our results show that the isotopic approach has limited applicability for the study of animal movements in the northeast Atlantic at a regional scale, but is potentially useful for the study of long-distance migrations between large marine systems.
\end{abstract}

KEY WORDS: Feeding ecology $\cdot$ Marine isoscapes $\cdot$ Migratory movements $\cdot$ Procellariiformes $\cdot$ Trophic niche

\footnotetext{
Resale or republication not permitted without
} written consent of the publisher

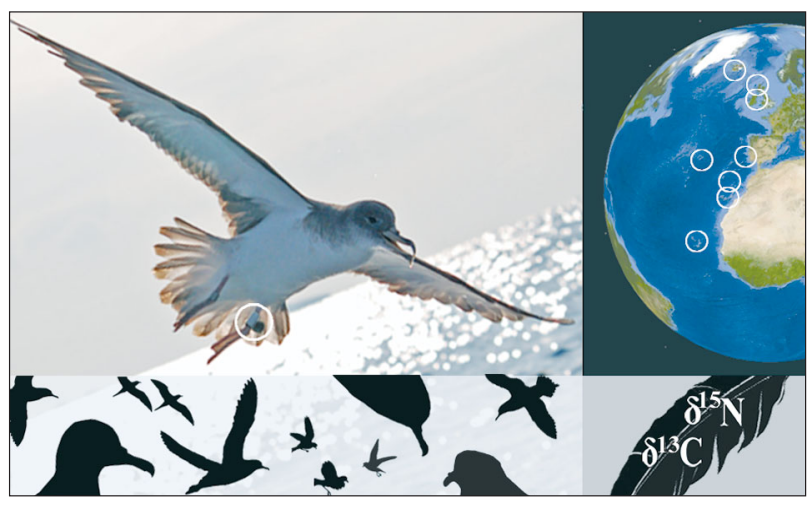

Stable isotope analysis combined with movement tracking reveals the effect of baseline geographic variability on the isotopic signatures of marine animals and improves our understanding of their spatial and feeding ecology

Image: Jose L. Roscales \& Maties Rebassa

\section{INTRODUCTION}

Stable isotope analyses (SIA) of carbon (C) and nitrogen $(\mathrm{N})$ have been extensively used as dietary tracers in animals at different ecological levels, from individuals to communities. Since isotope ratios in consumer tissues reflect those of their prey in a predictable manner (DeNiro \& Epstein 1978, 1981, Hobson \& Clark 1992), SIA provides valuable information on feeding ecology and shows some specific advantages over conventional dietary studies (i.e. reduced time integration or bias towards hard-bodied prey), detailed in Barrett et al. (2007). Although primarily applied to terrestrial environments, an increasing number of studies use the 
technique to study the trophic structure of marine food webs (Hobson \& Welch 1992), including trophic relationships in bird and mammal communities (Lesage et al. 2001, Forero et al. 2004), as well as more specific questions of spatial and temporal variability in diets (Cherel et al. 2007). In addition, isotopic approaches can integrate better than other methodologies the different dimensions that shape a species' niche (Cherel et al. 2007, Layman et al. 2007, Newsome et al. 2007). However, marine environments show complex spatial variations in baseline isotope signatures (Graham et al. 2009) and these are also reflected in consumer tissues. While this can obscure feeding relationships when comparing animals from different localities, abrupt changes in, as well as latitudinal and longitudinal geographic patterns of marine isoscapes have also been widely used to trace movements of wildlife (Rubenstein \& Hobson 2004, Cherel \& Hobson 2007, Ramos et al. 2009a). Overall, there is increasing interest in using stable isotopes to identify and link breeding and wintering areas in all marine organisms (Gómez-Díaz \& González-Solís 2007, Caut et al. 2008, Rooker et al. 2008), as other intrinsic markers (i.e. biometric or genetic) show a limited capacity to identify them (Hobson 2008).

In spite of the wide application of SIA by scientists, it is often unclear whether isotop signatures resulting from trophic ecology can be overridden by differences in isotope baseline levels among food webs. For example, 2 relatively close populations from the same petrel species exploiting neighbouring water masses showed substantially distinct isotope signatures, even when their scavenging role in the ecosystem was essentially maintained throughout the entire distribution of the species (Forero et al. 2005). This illustrates that the interpretation of animal isotopic data when geographic variability is uncertain can be misleading. The lack of knowledge of the marine isoscapes across broad marine areas, such as for example tropical and subtropical regions compared to temperate and polar regions, constitutes a real challenge, especially for the study of wide-ranging marine species (Jaquemet \& McQuaid 2008). Therefore, expanding our knowledge of isotope biogeographic trends as well as evaluating their influence over animal isotope signatures seems an appropriate research direction to increase the applicability of SIA to marine environments (West et al. 2006).

Seabirds offer an excellent opportunity to study the influence of feeding ecology and baseline isotope levels on the spatial dynamics of stable isotope signatures in the marine environment. They are readily accessible on their breeding grounds and show wide breeding distributions and rich species composition (Brooke 2004). Moreover, SIA on feathers can be exceptionally useful when moulting patterns are known because fully grown feathers become inert, integrating the isotopic forms assimilated through the diet when and where they were grown (Bearhop et al. 2002). In addition, it is now possible to track seabird movements over long periods of time by instrumenting birds with global location sensing (GLS) devices. Therefore, by tracking the movements of seabirds as well as analysing the stable isotope signatures of feathers with known moulting patterns, feather isotopic information can be linked to specific geographic areas (Ramos et al. 2009a, González-Solís et al. 2011) and thus the biogeographic patterns of stable isotopes in the marine environment can be revealed. In the present study, we analysed the isotope signatures of $\mathrm{C}$ and $\mathrm{N}$ in the first (innermost) primary feather (P1) of 11 petrel and shearwater species breeding throughout 16 northeast (NE) Atlantic localities and used GLS devices to establish the moult geographical boundaries of the P1 feathers for some populations. We first checked the existence of latitudinal and longitudinal isotopic gradients or abrupt changes as well as possible spatial structures in $\delta^{15} \mathrm{~N}$ and $\delta^{13} \mathrm{C}$ values. We then analysed the differences in $\mathrm{C}$ and $\mathrm{N}$ isotope signatures at inter- and intraspecific levels. In brief, if biogeographic trends in baseline isotope levels predominate over the influence of the feeding ecology, isotope signatures of the species sampled at different localities should correlate with the geographic distance between colonies or the geographic coordinates across the species' ranges (latitude and longitude). If the reverse is true and the trophic ecology of seabird populations remains consistent, isotope signatures of seabird species should hold over their entire breeding range, regardless of breeding locality.

\section{MATERIALS AND METHODS}

Study species, area and field procedure. We selected 11 out of a total of 14 Procellariiform species nesting on the NE Atlantic archipelagos from Cape Verde $\left(20^{\circ} 15^{\prime} 16^{\prime \prime} \mathrm{N}\right)$ to Iceland $\left(60^{\circ} 50^{\prime} 49^{\prime \prime} \mathrm{N}\right.$ ) (see Table 1). Most petrels studied are relatively abundant and have a wide distribution in the NE Atlantic. Cory's shearwater Calonectris diomedea borealis, Bulwer's petrel Bulweria bulwerii, Madeiran storm-petrel Oceanodroma castro, white-faced storm-petrel Pelagodroma marina and Macaronesian shearwater Puffinus baroli breed throughout the mid-north Atlantic (Macaronesian islands). Fea's petrel Pterodroma feae nests on Madeira and Cape Verde islands. Cape Verde little shearwater Puffinus boydi and Cape Verde shearwater C. edwardsii are endemic to the Cape Verde archipelago. Leach's storm-petrel $O$. leucorhoa breeds close to the Arctic Circle, while the Manx shearwater Puffinus 

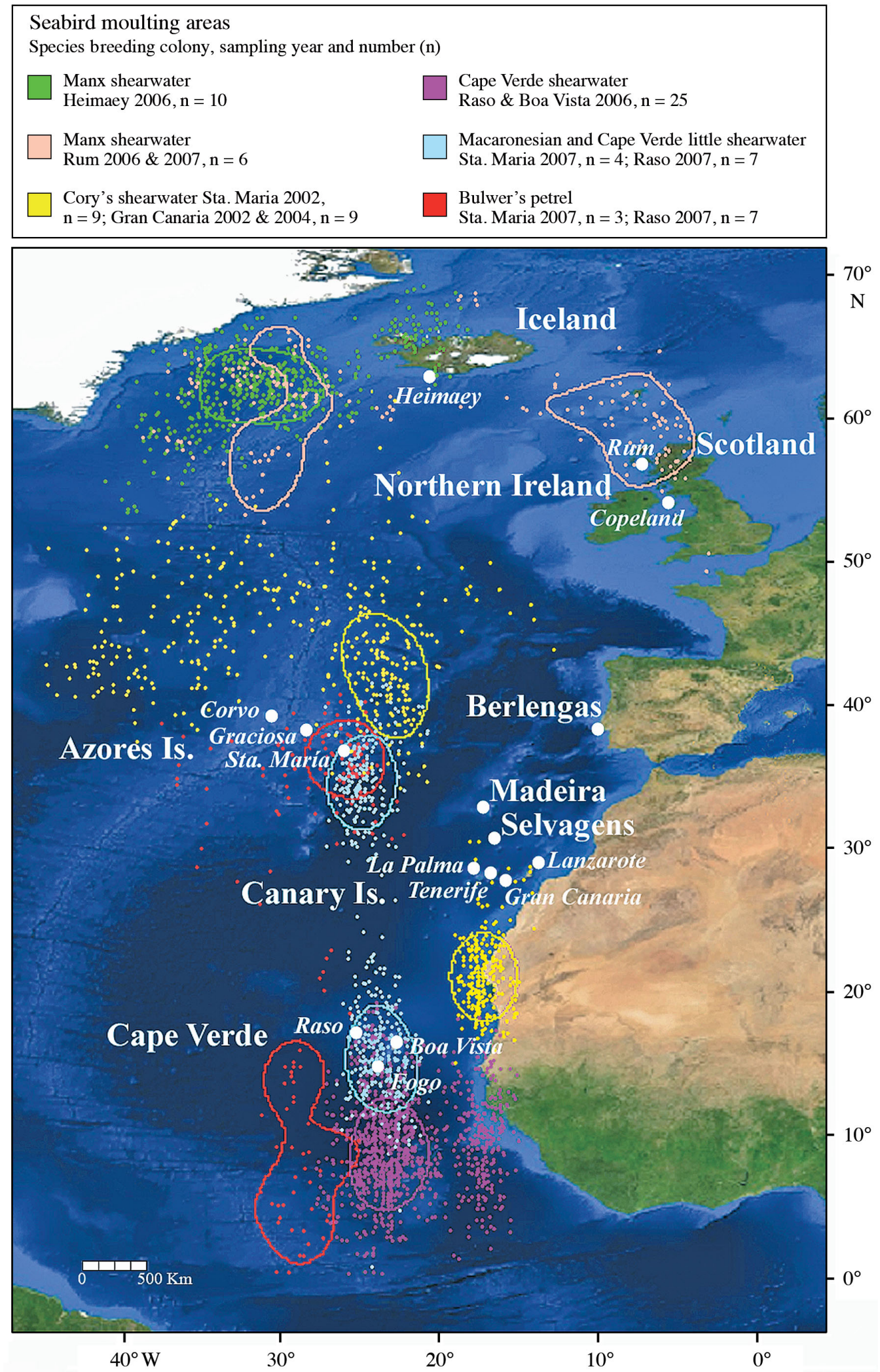

Fig. 1. Sampled breeding colonies (white dots) and moulting areas (locations in dots and kernel densities at $50 \%$ as a contour line) from birds tracked with global location sensing devices over a month prior to postnuptial migration. Taxonomic names are given in Table 1 
puffinus and the European storm-petrel Hydrobates pelagicus have the widest latitudinal distributions in the present study, breeding from close to the Arctic Circle down to the Canary Islands.

From 2002 to 2007 we sampled P1 feathers from adult birds from 16 localities across the NE Atlantic (Fig. 1). The bird were captured in their burrows or by using mist nets. Adults moult primary feathers annually. Manx, Cory's and Cape Verde shearwaters moult the P1 feather at the end of the breeding period, when they are still feeding their chick (Monteiro \& Furness 1996, Ginn \& Melville 2000, Ramos et al. 2009a, 2009c). The European storm-petrel moults the P1 feather after egg-laying (Cramp \& Simmons 1977, Monteiro et al. 1996, Arroyo et al. 2004, Brooke 2004). The Macaronesian shearwater, Cape Verde little shearwater, Madeiran storm-petrel and Bulwer's petrel moult their P1 feathers at the end of the breeding period, just before migration (Cramp \& Simmons 1977, Bolton et al. 2008, authors' pers. obs.). Leach's storm-petrel moults the P1 feather after departing the colonies (Hedd \& Montevecchi 2006). Not much is known about the moulting patterns of Fea's petrel and white-faced storm-petrel. However, their morphological and ecological similarities with the rest of the mid-north Atlantic petrel community and our personal observations in the field suggest that most individuals also moult their P1 feathers just before dispersion in subtropical waters (Spear \& Ainley 2007). Therefore, with the exception of Leach's storm-petrel, most sampled feathers should reflect the isotopic composition of the breeding areas. To test inter-annual variability in stable isotope signatures, some localities were re-sampled in different years. All feathers were conserved in polyethylene bags until SIA.

To establish the geographical boundaries within which the P1 feathers were grown, we used GLS devices based on recording light levels, which can be deployed on a bird all year round and will give 2 positions per day with an accuracy (mean \pm SD) of $186 \pm 114 \mathrm{~km}$ (Phillips et al. 2004). Overall, we obtained tracking from 74 GLS. Specifically, we tracked the movements of Cory's shearwaters breeding in the Azores ( $\mathrm{n}=9$ in 2002) and the Canary Islands ( $\mathrm{n}=6$ in 2002); Cape Verde shearwaters ( $\mathrm{n}=24$ in 2006) and Cape Verde little shearwaters ( $\mathrm{n}=7$ in 2007) breeding in Cape Verde; Bulwer's petrels breeding in the Azores $(\mathrm{n}=3$ in 2007) and Cape Verde ( $\mathrm{n}=5$ in 2007); Macaronesian shearwaters breeding in the Azores ( $\mathrm{n}=4$ in 2007); and Manx shearwaters breeding in Scotland ( $\mathrm{n}=4$ in 2006 and $n=2$ in 2007) and Iceland ( $\mathrm{n}=10$ in 2006) (Fig. 1). The moulting areas of the seabirds were inferred from the positions of the birds during the month prior to their migration (see Table 2), in which most seabirds are thought to moult P1 feather (see previous paragraph; the tracked birds were not used for SIA).
Isotope analysis. All feathers were cleaned in a solution of $\mathrm{NaOH}(0.25 \mathrm{M})$ and oven-dried at $60^{\circ} \mathrm{C}$. To homogenise samples for isotope analysis, large feathers were ground to powder using a cryogenic impact grinder (Freezer/mill 6750, Spex Certiprep) operating at liquid-nitrogen temperature, whereas small feathers were meticulously cut with stainless steel scissors into tiny fragments. Weighed sub-samples $(0.36 \mathrm{mg})$ of feathers were placed into tin buckets and crimped for combustion. Isotope analyses were carried out by elemental analysis-isotope ratio mass spectrometry (EAIRMS) using a ThermoFinnigan Flash 1112 elemental analyser coupled to a Delta isotope ratio mass spectrometer via a CONFLOIII interface (Serveis Científico-Tècnics, University of Barcelona). Stable isotope ratios were expressed in conventional notation as parts per thousand (\%) according to the following equation:

$$
\delta X=\left[\left(\mathrm{R}_{\text {sample }} / \mathrm{R}_{\text {standard }}\right)-1\right] \times 1000
$$

where $X$ is ${ }^{15} \mathrm{~N}$ or ${ }^{13} \mathrm{C}$, and $\mathrm{R}$ is the corresponding ratio ${ }^{15} \mathrm{~N}:{ }^{14} \mathrm{~N}$ or ${ }^{13} \mathrm{C}:{ }^{12} \mathrm{C}$. The standards used for ${ }^{15} \mathrm{~N}$ and ${ }^{13} \mathrm{C}$ were atmospheric nitrogen (AIR) and Peedee Belemnite (PDB), respectively. Precision and accuracy for $\delta^{13} \mathrm{C}$ measurements was $\leq 0.1 \%$, and for $\delta^{15} \mathrm{~N}$ it was $\leq 0.3 \%$.

Data analysis. The normality of $\delta^{13} \mathrm{C}$ and $\delta^{15} \mathrm{~N}$ was validated by checking $\mathrm{Q}-\mathrm{Q}$ plots and by the ShapiroWilks test. Moulting areas of the NE Atlantic petrels and shearwaters were assessed by means of $50 \%$ density kernel analysis on the locations obtained from GLS devices during the month prior to the onset of migration (see Table 2). Positions were calculated using TransEdit and BirdTracker (British Antarctic Survey) by inspecting the integrity of the light curve day by day and fitting dawn and dusk times. To filter unrealistic positions, we removed (1) those obtained from light curves showing interferences at dawn or dusk; (2) those with a speed index $>25 \mathrm{~km} \mathrm{~h}^{-1}$, as calculated by the square root of the average speed of the segments formed with the 2 preceding and the 2 following positions; we applied such a restrictive speed filter due to the proximity of the equinoxes for several birds; and (3) those within the 10 closest days to the equinoxes. Since we could only track birds from a few populations and species, in order to investigate the existence of biogeographical patterns in the stable isotope signatures in feathers, we used the position of the breeding colony as a proxy of the area where the P1 feather was grown. We used this criterion to guarantee homogeneous treatment for all sampled species. This is unlikely to introduce a strong bias, since populations included in the present study are separated by several thousand kilometres and in some cases are located in different oceanographic regimes, whereas moulting areas of the tracked birds only exceeded their colony sites by a few hundred kilometres (Fig. 1). 
To check for possible isotope biogeographic gradients, we correlated the stable isotope signatures of feathers with latitude and longitude coordinates for each sampled locality using linear and quadratic regressions. To assess the existence of a spatial pattern in the isotopic variation across the breeding range of each species, we tested the correlation between geographic distances of breeding colonies and isotopic differences (calculated as Euclidean distances of colony pairs). In this case, we first applied multidimensional scaling of dissimilarity data by PROXCAL analysis using SPSS 12.0. The method tries to find the underlying structure in a set of proximity measures among objects arranged in a 2-dimensional space. Then we applied Procrustes analysis (least-squares orthogonal mapping), a nonparametric approach for comparing any 2 kinds of non-linearised data sets (Jackson 1995, Peres-Neto \& Jackson 2001). The method is based on matching corresponding points (landmarks) from each of the 2 data sets, geographic or isotopic coordinates of each colony, and provides a measure of fit $\mathrm{m}^{2}$, which decreases with an increasing correlation. The significance test of the $\mathrm{m}^{2}$ statistic was determined by employing a randomisation approach to one of the data sets (Protest).

We checked possible differences in stable isotope signatures among breeding colonies within archipelagos for each species (e.g. Cory's shearwater in 4 of the Canary Islands) using Student's t-test or 1-way ANOVA. Since we found a negligible effect of breeding colony (see 'Results') over isotope signatures of seabirds within archipelagos, we grouped breeding colonies of each species shaping the factor breeding locality (see Table 1) to evaluate isotopic variability among species and their distributions. Because our sample design is unbalanced and shows some empty cells (the sampled species do not all breed in all the localities sampled), analyses of variability of $\mathrm{C}$ and $\mathrm{N}$ stable isotope signatures were performed applying separate generalised linear models (GLM; Type IV SS for unbalanced designs, SPSS v. 15) using each stable isotope signature as a response variable. Factors used as explanatory variables for the model were species (11 levels), breeding locality (9 levels), and their interaction. Finally, since the model showed a significant interaction between species and breeding locality, we compared isotope signatures within species means among breeding localities (e.g. Cory's shearwater from the Azores, Canary Islands, Madeira, etc.) as well as among species within each breeding locality using 1-way ANOVA. Inter-annual differences within a locality sampled in successive breeding periods were tested using a $t$-test (for 2 consecutive years) or ANOVA (>2 yr). Results are shown as mean $\pm \mathrm{SE}$, unless otherwise indicated.

\section{RESULTS}

Stable isotope signatures of sampled feathers from NE Atlantic Procellariiformes are summarised in Table 1. Migration onset for each of the the 6 GLStracked species is listed in Table 2. The ShapiroWilks test and Q-Q plots showed no significant departure from a normal distribution for $\delta^{13} \mathrm{C}$ and $\delta^{15} \mathrm{~N}$ among breeding colonies and species (all $\mathrm{p}>$ 0.05). To evaluate the potential influence of sampling year on seabird stable isotope signatures, we examined inter-year differences for colonies sampled in successive breeding periods (summarised in Table 3). Cory's shearwaters from Gran Canaria (Canary Islands) and Santa Maria (Azores) sampled in 2002 and 2003 did not show differences between years within each colony, respectively. Similarly, we did not find significant differences in the isotope signatures of Bulwer's petrels from Madeira sampled in 2004 and 2005, nor for the Madeiran storm-petrel from Selvagens sampled in 3 successive years (2003 to 2005). Only $\delta^{15} \mathrm{~N}$ values in feathers of Madeiran storm-petrel from Graciosa (Azores) showed significant differences between years (mean $\delta^{15} \mathrm{~N}$ value increased $0.5 \%$ from 2002 to 2003).

\section{Biogeographical structure in $\delta^{13} \mathrm{C}$ and $\delta^{15} \mathrm{~N}$ signatures}

Although some species showed clear differences in isotope signatures across their breeding range, the stable isotope signatures grouped mainly by species regardless of breeding locality (Fig. 2). Regression models based on stable isotope composition in P1 feathers showed significant spatial gradients only for Cory's shearwater. In this case, we found an inverse relationship between $\delta^{13} \mathrm{C}$ and latitude $\left(F_{1,233}=373.99\right.$, $\mathrm{p}<0.001 ; \mathrm{R}^{2}$ linear $=0.62, \mathrm{R}^{2}$ quadratic $\left.=0.67\right)$. Stable $\mathrm{C}$ signatures from Cory's shearwater feathers (mean \pm $\mathrm{SE})$ tended to decrease from south to north $(-14.09 \pm$ $0.10 \%$ in Gran Canaria, Canary Islands; $-16.15 \pm$ $0.10 \%$ in Corvo, Azores). Cape Verde shearwaters showed unexpected low values $(-15.73 \pm 0.13 \%)$. A regression model including Cape Verde shearwater and Cory's shearwater showed a significant relationship between $\delta^{13} \mathrm{C}$ and latitude, but the $\mathrm{R}^{2}$ value decreased considerably $\left(\mathrm{R}^{2}\right.$ linear $=0.16, \mathrm{R}^{2}$ quadratic $=0.53 ; \mathrm{p}<0.001)$. No significant associations were found between $\delta^{13} \mathrm{C}$ and longitude or between $\delta^{15} \mathrm{~N}$ and geographical coordinates for any of the species studied.

To test the existence of spatial patterns of isotopic variation across the breeding range of each seabird specie, we examined the correlation between geo- 
Table 1. Mean and coefficient of variation $(\mathrm{CV}=\mathrm{SD} / \mathrm{mean})$ for stable isotope signatures of nitrogen and carbon in the first primary feather from all 11 species studied

\begin{tabular}{|c|c|c|c|c|c|c|c|c|}
\hline \multirow[t]{2}{*}{ Species } & \multirow[t]{2}{*}{ Locality } & \multirow[t]{2}{*}{ Colony } & \multirow[t]{2}{*}{$\mathrm{n}$} & \multicolumn{2}{|c|}{$-\delta^{13} \mathrm{C}-$} & \multicolumn{2}{|c|}{$-\delta^{15} \mathrm{~N}-$} & \multirow[t]{2}{*}{ Year } \\
\hline & & & & Mean $(\%)$ & $\mathrm{CV}$ & Mean $(\%$ ) & $\mathrm{CV}$ & \\
\hline \multicolumn{9}{|c|}{ Calonectris diomedea borealis (Cory's shearwater) } \\
\hline & \multirow[t]{3}{*}{ Azores } & Santa Maria & 69 & -16.23 & 0.02 & 13.16 & 0.05 & 2002,2003 \\
\hline & & Graciosa & 15 & -16.06 & 0.03 & 12.63 & 0.06 & 2003 \\
\hline & & Corvo & 13 & -16.15 & 0.02 & 12.52 & 0.08 & 2003 \\
\hline & \multirow[t]{4}{*}{ Canaries } & Gran Canaria & 48 & -14.09 & 0.05 & 13.20 & 0.05 & 2002,2003 \\
\hline & & Lanzarote & 16 & -14.30 & 0.08 & 12.92 & 0.06 & 2003 \\
\hline & & La Palma & 25 & -14.16 & 0.08 & 12.56 & 0.10 & 2006 \\
\hline & & Tenerife & 9 & -13.87 & 0.07 & 12.87 & 0.02 & 2003 \\
\hline & Madeira & Madeira & 15 & -16.06 & 0.04 & 12.91 & 0.07 & 2004 \\
\hline & Selvagens & Selvagens & 8 & -15.25 & 0.04 & 12.58 & 0.03 & 2004 \\
\hline & Berlengas & Berlengas & 16 & -16.37 & 0.04 & 13.31 & 0.05 & 2004 \\
\hline \multicolumn{9}{|c|}{ Calonectris edwardsii (Cape Verde shearwater) } \\
\hline & Cape Verde & Boa Vista & 28 & -15.73 & 0.04 & 12.28 & 0.09 & 2002 \\
\hline \multicolumn{9}{|c|}{ Bulweria bulwerii (Bulwer's petrel) } \\
\hline & Azores & Santa Maria & 10 & -16.44 & 0.03 & 11.79 & 0.05 & 2003 \\
\hline & \multirow[t]{3}{*}{ Canaries } & Lanzarote & 10 & -16.12 & 0.02 & 11.90 & 0.05 & 2003 \\
\hline & & La Palma & 3 & -16.37 & 0.01 & 11.63 & 0.01 & 2006 \\
\hline & & Gran Canaria & 4 & -15.81 & 0.02 & 11.42 & 0.05 & 2003 \\
\hline & Madeira & Madeira & 12 & -16.27 & 0.02 & 12.10 & 0.07 & 2004,2005 \\
\hline & Selvagens & Selvagens & 11 & -16.41 & 0.02 & 11.36 & 0.03 & 2003 \\
\hline & Cape Verde & Raso & 10 & -16.17 & 0.01 & 11.84 & 0.08 & 2007 \\
\hline \multicolumn{9}{|c|}{ Hydrobates pelagicus (European storm-petrel) } \\
\hline & Canaries & Lanzarote & 11 & -16.01 & 0.07 & 13.15 & 0.02 & 2003 \\
\hline & Iceland & Heimaey & 10 & -16.53 & 0.05 & 15.15 & 0.10 & 2006 \\
\hline & North Ireland & Copeland & 15 & -16.51 & 0.05 & 15.32 & 0.08 & 2005 \\
\hline \multicolumn{9}{|c|}{ Oceanodroma castro (Madeiran storm-petrel) } \\
\hline & Azores & Santa Maria & 71 & -16.67 & 0.03 & 12.21 & 0.05 & 2003 \\
\hline & & Graciosa & 35 & -16.68 & 0.03 & 12.36 & 0.06 & 2002,2003 \\
\hline & Canaries & Lanzarote & 8 & -17.18 & 0.03 & 12.60 & 0.04 & 2003 \\
\hline & Madeira & Madeira & 4 & -17.12 & 0.03 & 12.32 & 0.07 & 2005 \\
\hline & Selvagens & Selvagens & 23 & -17.06 & 0.03 & 12.13 & 0.06 & 2003, 2004, 2005 \\
\hline & Berlengas & Berlengas & 8 & -16.87 & 0.04 & 12.58 & 0.07 & 2004 \\
\hline & Cape Verde & Raso & 10 & -16.59 & 0.02 & 12.58 & 0.09 & 2006 \\
\hline \multicolumn{9}{|c|}{ Puffinus baroli (Macaronesian shearwater) } \\
\hline & Azores & Santa Maria & 9 & -18.26 & 0.03 & 9.27 & 0.25 & 2003 \\
\hline & Canaries & Lanzarote & 4 & -17.18 & 0.02 & 12.60 & 0.13 & 2007 \\
\hline & Selvagens & Selvagens & 2 & -18.81 & 0.01 & 10.67 & 0.07 & 2004 \\
\hline \multicolumn{9}{|c|}{ Puffinus boydi (Cape Verde little shearwater) } \\
\hline & Cape Verde & Raso & 10 & -16.76 & 0.02 & 8.63 & 0.13 & 2005 \\
\hline \multicolumn{9}{|c|}{ Pelagodroma marina (White-faced storm-petrel) } \\
\hline & Canaries & Lanzarote & 6 & -17.63 & 0.01 & 13.62 & 0.06 & 2007 \\
\hline & Selvagens & Selvagens & 10 & -17.42 & 0.02 & 12.83 & 0.11 & 2006 \\
\hline Pterodro & (Fea's petrel) & & & & & & & \\
\hline & Cape Verde & Fogo & 10 & -15.63 & 0.02 & 13.38 & 0.03 & 2007 \\
\hline Puffinus & (Manx shearw & & & & & & & \\
\hline & Canaries & La Palma & 2 & -16.60 & 0.08 & 14.17 & 0.18 & 2006 \\
\hline & Iceland & Heimaey & 10 & -16.06 & 0.01 & 18.19 & 0.03 & 2006 \\
\hline & North Ireland & Copeland & 10 & -16.33 & 0.02 & 17.75 & 0.06 & 2005 \\
\hline & Scotland & Rum & 9 & -16.12 & 0.02 & 18.21 & 0.03 & 2006 \\
\hline Oceanoc & ucorhoa (Leach' & petrel) & & & & & & \\
\hline & Iceland & Heimaey & 10 & -17.72 & 0.02 & 13.17 & 0.07 & 2006 \\
\hline
\end{tabular}

graphic and isotopic distances of colony pairs. For all 5 species-complexes analysed (Cory's shearwater plus Cape Verde shearwater; Manx shearwater; Bulwer's petrel; Macaronesian shearwater plus Cape
Verde little shearwater; and Madeiran storm-petrel), Procrustes analyses revealed no significant correlation between geographic and isotopic distances among colonies, although for Calonectris spp. it was 
Table 2. Year, number of birds tracked and migration onset for each population and species included in Fig. 1. The tracked period shown in Fig. 1 includes the post-breeding locations for the month prior to the migration onset, when the first primary feather is supposed to have been moulted. Onset of migration was determined visually from the tracked trajectories. Taxonomic names are given in Table 1

\begin{tabular}{|c|c|c|c|c|c|}
\hline Species & Locality & Colony & Year & $\mathrm{n}$ & $\begin{array}{c}\text { Migration onset } \\
\text { (mean date } \pm \text { SD in days) }\end{array}$ \\
\hline \multirow[t]{3}{*}{ Cory's shearwater } & \multirow[t]{2}{*}{ Canaries } & Gran Canaria & 2002 & 6 & $14 \mathrm{Nov} \pm 6.68$ \\
\hline & & Gran Canaria & 2004 & 3 & $15 \mathrm{Nov} \pm 6.84$ \\
\hline & Azores & Santa Maria & 2002 & 9 & $20 \mathrm{Nov} \pm 10.2$ \\
\hline \multirow{2}{*}{ Cape Verde shearwater } & \multirow{2}{*}{ Cape Verde } & Boa Vista & 2006 & 12 & $18 \mathrm{Nov} \pm 4.18$ \\
\hline & & Raso & 2006 & 13 & $15 \mathrm{Nov} \pm 3.56$ \\
\hline Macaronesian shearwater & Azores & Santa Maria & 2007 & 4 & 20 May \pm 0.00 \\
\hline Cape Verde little shearwater & Cape Verde & Raso & 2007 & 7 & 16 May \pm 12.2 \\
\hline \multirow[t]{2}{*}{ Bulwer's petrel } & Azores & Santa Maria & 2007 & 3 & $1 \mathrm{Sep} \pm 1.41$ \\
\hline & Cape Verde & Raso & 2007 & 7 & 21 Oct \pm 12.5 \\
\hline \multirow[t]{2}{*}{ Manx shearwater } & Iceland & Heimaey & 2006 & 10 & $10 \mathrm{Sep} \pm 5.75$ \\
\hline & Scotland & Rum & 2006 & 4 & $26 \mathrm{Sep} \pm 0.34$ \\
\hline
\end{tabular}

Table 3. $\delta^{13} \mathrm{C}$ and $\delta^{15} \mathrm{~N}$ (mean $\pm \mathrm{SE}$ ) in the first primary feather by sampling year, and summarised statistics from Student's $t$-test or ANOVA evaluating interannual differences in the isotope signatures. nd: not determined. Taxonomic names are given in Table 1

\begin{tabular}{|c|c|c|c|c|c|c|c|c|c|}
\hline \multirow[t]{2}{*}{ Species } & \multirow[t]{2}{*}{ Breeding colony } & \multirow[t]{2}{*}{ Isotope } & \multicolumn{4}{|c|}{ Isotope signature $(\%)$} & \multicolumn{3}{|c|}{$\begin{array}{l}\text { Student's } t \\
\text { or ANOVA }\end{array}$} \\
\hline & & & 2002 & 2003 & 2004 & 2005 & df & $t$ or $F$ & $\mathrm{p}$ \\
\hline Cory's shearwater & $\begin{array}{l}\text { Santa Maria } \\
\text { (Azores) } \\
\text { Gran Canaria } \\
\text { (Canaries) }\end{array}$ & $\begin{array}{l}\delta^{15} \mathrm{~N} \\
\delta^{13} \mathrm{C} \\
\delta^{15} \mathrm{~N} \\
\delta^{13} \mathrm{C}\end{array}$ & $\begin{array}{r}13.2 \pm 0.6 \\
-16.2 \pm 2.3 \\
13.1 \pm 0.6 \\
-14.1 \pm 0.7\end{array}$ & $\begin{array}{r}13.1 \pm 0.6 \\
-16.2 \pm 2.4 \\
13.4 \pm 0.7 \\
-14.1 \pm 0.8\end{array}$ & $\begin{array}{l}\text { nd } \\
\text { nd } \\
\text { nd } \\
\text { nd }\end{array}$ & $\begin{array}{l}\text { nd } \\
\text { nd } \\
\text { nd } \\
\text { nd }\end{array}$ & $\begin{array}{l}68 \\
68 \\
47 \\
47\end{array}$ & $\begin{array}{c}-0.01^{\mathrm{a}} \\
-0.12^{\mathrm{a}} \\
-1.27^{\mathrm{a}} \\
0.35^{\mathrm{a}}\end{array}$ & $\begin{array}{l}0.99 \\
0.91 \\
0.21 \\
0.73\end{array}$ \\
\hline Bulwer's petrel & Madeira & $\begin{array}{l}\delta^{15} \mathrm{~N} \\
\delta^{13} \mathrm{C}\end{array}$ & $\begin{array}{l}\text { nd } \\
\text { nd }\end{array}$ & $\begin{array}{l}\text { nd } \\
\text { nd }\end{array}$ & $\begin{array}{r}12.2 \pm 0.9 \\
-16.2 \pm 0.3\end{array}$ & $\begin{array}{r}11.8 \pm 0.4 \\
-16.3 \pm 0.2\end{array}$ & $\begin{array}{l}11 \\
11\end{array}$ & $\begin{array}{l}0.77^{\mathrm{a}} \\
0.50^{\mathrm{a}}\end{array}$ & $\begin{array}{l}0.46 \\
0.63\end{array}$ \\
\hline $\begin{array}{l}\text { Madeiran } \\
\text { storm-petrel }\end{array}$ & $\begin{array}{l}\text { Graciosa (Azores) } \\
\text { Selvagens }\end{array}$ & $\begin{array}{l}\delta^{15} \mathrm{~N} \\
\delta^{13} \mathrm{C} \\
\delta^{15} \mathrm{~N} \\
\delta^{13} \mathrm{C}\end{array}$ & $\begin{array}{l}12.1 \pm 0.7 \\
-16.7 \pm 0.5 \\
\text { nd } \\
\text { nd }\end{array}$ & $\begin{array}{r}12.6 \pm 0.8 \\
-16.6 \pm 0.6 \\
12.3 \pm 0.7 \\
-17.1 \pm 0.3\end{array}$ & $\begin{array}{c}\text { nd } \\
\text { nd } \\
12.4 \pm 0.6 \\
-17.4 \pm 0.5\end{array}$ & $\begin{array}{c}\text { nd } \\
\text { nd } \\
12.0 \pm 0.7 \\
-16.9 \pm 0.5\end{array}$ & $\begin{array}{c}34 \\
34 \\
2,22 \\
2,22\end{array}$ & $\begin{array}{c}-2.23^{\mathrm{a}} \\
-0.66^{\mathrm{a}} \\
0.87^{\mathrm{b}} \\
2.38^{\mathrm{b}}\end{array}$ & $\begin{array}{l}0.03 \\
0.52 \\
0.44 \\
0.12\end{array}$ \\
\hline
\end{tabular}

marginally non-significant (Calonectris spp.: $\mathrm{m}^{2}=$ $0.68, \mathrm{p}=0.06$; Bulweria bulwerii: $\mathrm{m}^{2}=0.91, \mathrm{p}=0.82$; Puffinus baroli and P. boydi: $m^{2}=0.15, \mathrm{p}=0.14$; $P$. puffinus: $\mathrm{m}^{2}=0.48, \mathrm{p}=0.22$; Oceanodroma castro: $\left.m^{2}=0.62, \mathrm{p}=0.23\right)$.

\section{Inter-specific and inter-locality variability in $\delta^{13} \mathbf{C}$ and $\delta^{15} \mathrm{~N}$ signatures}

Overall, $\delta^{13} \mathrm{C}$ and $\delta^{15} \mathrm{~N}$ values mostly grouped by species, and not by geographic proximity, except for North Atlantic localities (Fig. 2). Northern seabird populations were clearly segregated from mid-north Macaronesian localities due to their greater $\delta^{15} \mathrm{~N}$ signatures, with the exception of Leach's storm-petrel, which showed isotope signatures within the range for the Macaronesian breeders.
Stable C isotope signatures in the P1 feathers ranged from $-18.81 \pm 0.13 \%$ o (Macaronesian shearwater from Selvagens Islands) to $-13.87 \pm 0.32 \%$ o (Cory's shearwater from Tenerife, Canary Islands). Stable $\mathrm{N}$ isotope signatures ranged from higher values in Manx shearwaters from Scotland $(18.21 \pm 0.16 \%$ ) to lower values in Cape Verde little shearwaters (8.63 $\pm 0.36 \%$ ), although most sampled colonies ranged within narrower $\delta^{15} \mathrm{~N}$ values, from 13.31 to $11.36 \%$ (Fig. 2). The GLMs explained up to 60.4 and $80.3 \%$ of the initial variance for $\delta^{15} \mathrm{~N}$ and $\delta^{13} \mathrm{C}$, respectively. All the included factors - species $\left(F_{10,608}=44.10\right.$ for $\delta^{15} \mathrm{~N}_{\text {; }}$ $F_{10,608}=48.87$ for $\delta^{13} C_{i}$ both $\left.\mathrm{p}<0.001\right)$, breeding locality $\left(F_{8,608}=10.38\right.$ and $F_{8,608}=3.60$ for $\delta^{15} \mathrm{~N}$ and $\delta^{13} \mathrm{C}$ respectively; both $\mathrm{p}<0.001)$, and their interaction $\left(F_{31,608}=2.09, \mathrm{p}<0.05\right.$ for $\delta^{15} \mathrm{~N}_{;} F_{31,608}=18.71, \mathrm{p}<0.001$ for $\delta^{13} \mathrm{C}$ ) - showed a significant effect in both models and thus none was removed. These results indicate 


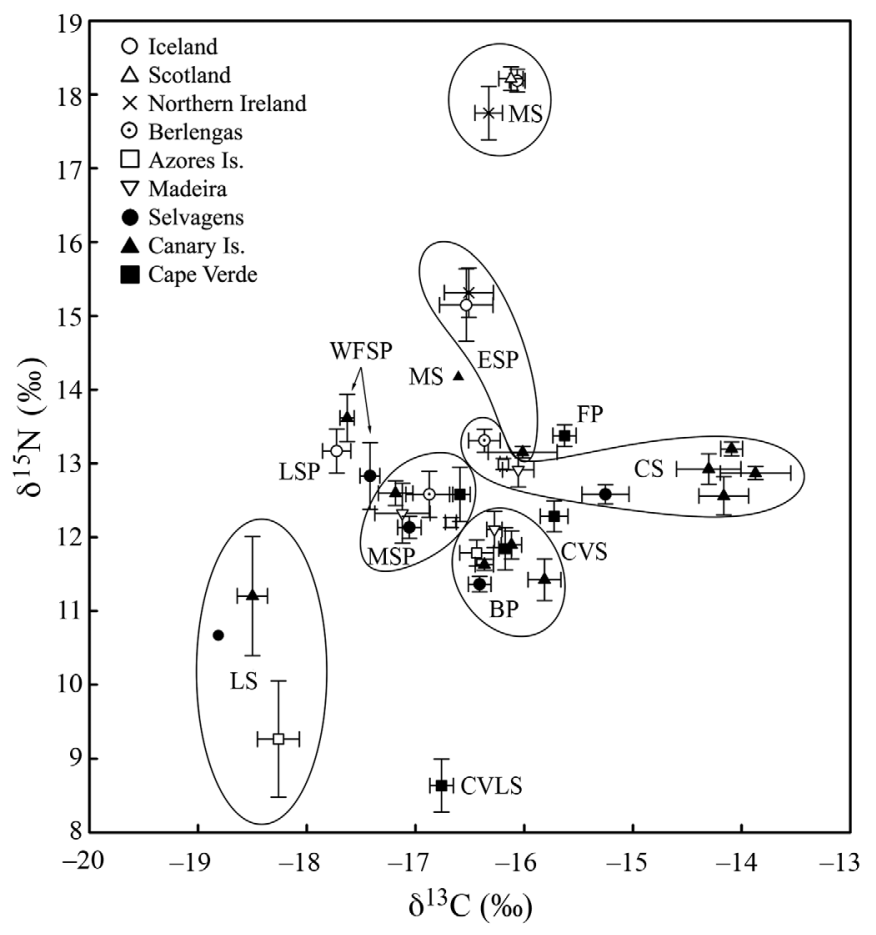

Fig. 2. Carbon and nitrogen stable isotope signatures (mean \pm SE) from the first primary feather from all 11 studied species' breeding colonies. Most species showed a small overlap in their isotope signatures, regardless of the breeding colony. Sampled colonies with $\mathrm{n}=2$ (Manx shearwater from Canary Islands and Macaronesian shearwater from Selvagens) appear without SE. Taxonomic names are given in Table 1, and species abbreviations in the legend to Table 4

that stable $\mathrm{N}$ values vary mainly among species but to a lesser extent also among localities, and further that these variations are not uniform but depend on the interaction between species and locality. The estimates of fixed effects showed that interaction in the case of $\mathrm{N}$ was mainly due to the lower $\delta^{15} \mathrm{~N}$ values found in the European storm-petrel from the Canary Islands compared with those from the northernmost Atlantic. In the case of $\mathrm{C}$, interaction was mainly due to the lower $\delta^{13} \mathrm{C}$ values found in Cory's shearwater breeding on the Canary Islands and the Selvagens compared to the remaining studied colonies (Fig. 2).

At an intraspecific level, both isotopes showed very low variability. Within breeding localities (Table 1), we did not find significant differences in $\delta^{13} \mathrm{C}$ among neighbouring breeding colonies, and only Cory's shearwater colonies from the Azores showed significant differences in their $\delta^{15} \mathrm{~N}$ signature because of the greater values from Santa Maria Island $\left(F_{2,96}=7.11, \mathrm{p}<0.05\right)$. Among breeding localities, we found significant differences in $\delta^{13} \mathrm{C}$ only for 2 species, Cory's shearwater and the Madeiran storm-petrel (Table 4). A post hoc test (Bonferroni) showed that in the case of Cory's shearwater these isotopic differences were due to the signifi- cantly greater $\delta^{13} \mathrm{C}$ values from the Canary Islands and the Selvagens. Madeiran storm-petrels showed significant differences in $\delta^{13} \mathrm{C}$ between archipelagos due to higher values in the Azores than in the Selvagens. In the case of stable $\mathrm{N}$ isotope signatures, we only found significant differences among breeding localities in the European storm-petrel and Manx shearwater (Table 4) due to the greater values in the North Atlantic compared to mid-north localities. In contrast, at the interspecific level, both stable $\mathrm{C}$ and $\mathrm{N}$ signatures showed great variability, and differences in $\delta^{13} \mathrm{C}$ and $\delta^{15} \mathrm{~N}$ (1way ANOVA) among species within each breeding locality were significant in most cases (Table 4).

\section{DISCUSSION}

The present study reveals an isotopic landscape in which most petrel and shearwater species showed differentiated isotopic spaces. Most populations from the same species grouped according to their isotope values regardless of their breeding colony (Fig. 2). This result suggests that the diet of most species remains fairly constant throughout their breeding distribution, and that $\delta^{15} \mathrm{~N}$ and $\delta^{13} \mathrm{C}$ signatures are primarily influenced by the feeding ecology of each species rather than by local values or biogeographical trends in the baseline isotope levels. Still, a few spatial differences and some intraspecific variability in the isotope values were found. Note, however, that some species (i.e. stormpetrels) were sampled in relatively few breeding localities (Table 1). Therefore, more isotopic variability might have arisen if more colonies had been included in the present study.

Since we sampled different populations from 2002 to 2007, our results could be confounded by some interannual variability in isotope signatures. Nevertheless, the present study included 5 seabird populations from 4 breeding localities sampled over 2 breeding periods, and interannual variations in seabird isotope signatures were minor. Only 1 species (Madeiran storm-petrel from Graciosa, Azores) showed significant yearly variations in $\delta^{15} \mathrm{~N}$ signatures, but the size of the difference was negligible when compared to interspecific differences. Similarly, previous studies rejected inter-annual and inter-seasonal $\delta^{15} \mathrm{~N}$ and $\delta^{13} \mathrm{C}$ as a relevant source of differences because temporal variations are considerably lower compared to inter-species or inter-locality differences (Forero et al. 2005, Quillfeldt et al. 2005, Ramos et al. 2009b). Temporal changes in baseline isotope levels at the decadal scale probably occur in most of the oceans, but at short time scales (though we used a multiyear sampling design ranging over $6 \mathrm{yr}$ ), our results suggest that interannual differences in baseline isotope signatures did not introduce a relevant bias. 
Table 4. Summary of 1-way ANOVAs of $\delta^{13} \mathrm{C}$ and $\delta^{15} \mathrm{~N}$ differences (a) among species within each breeding locality and (b) among breeding localities within each seabird species. Pairs of means differing significantly $(\mathrm{p}<0.05)$ by post hoc $t$-test are linked by the symbol ' $x$ '. Breeding localities: AZ: Azores, BE: Berlengas, CA: Canary Islands, CV: Cape Verde, IC: Iceland, MA: Madeira, NI: Northern Ireland, SC: Scotland, and SL: Selvagens. Species: BP: Bulwer's petrel, CS: Cory's shearwater, CVLS: Cape Verde little shearwater, CVS: Cape Verde shearwater, ESP: European storm-petrel, FP: Fea's petrel, LS: Macaronesian shearwater, LSP: Leach's storm-petrel, MS: Manx shearwater, MSP: Madeiran storm-petrel, and WFSP: white-faced storm-petrel. Taxonomic names are given in Table 1

\begin{tabular}{|c|c|c|c|c|c|}
\hline Locality & Isotope & $\mathrm{df}$ & $F$ & $\mathrm{p}$ & Post hoc $t$-test (Bonferroni) \\
\hline \multirow[t]{2}{*}{$\mathrm{CV}$} & $\delta^{13} \mathrm{C}$ & 4,67 & $63.38^{\mathrm{a}}$ & $<0.001$ & $\begin{array}{l}\mathrm{CVLS} \times \mathrm{FP}, \mathrm{BP}, \mathrm{CVS} ; \mathrm{MSP} \times \mathrm{FP}, \\
\mathrm{CVS}\end{array}$ \\
\hline & $\delta^{15} \mathrm{~N}$ & 4,67 & $13.18^{\mathrm{a}}$ & $<0.001$ & $\begin{array}{l}\mathrm{CVLS} \times \mathrm{FP}, \mathrm{BP}, \mathrm{CVS}, \mathrm{MSP} \\
\mathrm{BP} \times \mathrm{FP}\end{array}$ \\
\hline \multirow[t]{2}{*}{ CA } & $\delta^{13} \mathrm{C}$ & 6,145 & $55.33^{\mathrm{a}}$ & $<0.001$ & $\begin{array}{l}\mathrm{CS} \times \mathrm{BP}, \mathrm{MSP}, \mathrm{ESP}, \mathrm{LS}, \mathrm{MS}, \mathrm{WFSP} \\
\mathrm{ESP} \times \mathrm{LS}, \mathrm{WFSP} ; \mathrm{BP} \times \mathrm{WFSP}\end{array}$ \\
\hline & $\delta^{15} \mathrm{~N}$ & 6,145 & $8.65^{\mathrm{a}}$ & $<0.001$ & $\begin{array}{l}\text { LS } \times \text { CS, ESP, MS, WFSP; } \\
\mathrm{BP} \times \mathrm{CS}, \mathrm{WFSP}, \mathrm{MS}\end{array}$ \\
\hline \multirow[t]{2}{*}{ MA } & $\delta^{13} \mathrm{C}$ & 2,30 & $8.53^{\mathrm{a}}$ & 0.001 & $\mathrm{CS} \times \mathrm{MSP}$ \\
\hline & $\delta^{15} \mathrm{~N}$ & 2,30 & $2.99^{\mathrm{a}}$ & 0.67 & \\
\hline \multirow[t]{2}{*}{ SL } & $\delta^{13} \mathrm{C}$ & 4,53 & $8.54^{\mathrm{a}}$ & $<0.001$ & $\begin{array}{l}\mathrm{CS} \times \mathrm{LS}, \mathrm{BP}, \mathrm{MSP}, \mathrm{WFSP} ; \mathrm{BP} \times \mathrm{LS}, \\
\mathrm{MSP}, \mathrm{WFSP} ; \mathrm{LS} \times \mathrm{MSP} \text {, WFSP }\end{array}$ \\
\hline & $\delta^{15} \mathrm{~N}$ & 4,53 & $6.55^{\mathrm{a}}$ & $<0.001$ & $\mathrm{BP} \times \mathrm{CS}, \mathrm{WFSP}$ \\
\hline \multirow[t]{2}{*}{$\mathrm{AZ}$} & $\delta^{13} \mathrm{C}$ & 3,221 & $67.27^{\mathrm{a}}$ & $<0.001$ & $\mathrm{LS} \times \mathrm{CS}, \mathrm{BP}, \mathrm{MSP} ; \mathrm{MSP} \times \mathrm{CS}$ \\
\hline & $\delta^{15} \mathrm{~N}$ & 3,221 & $63.38^{\mathrm{a}}$ & $<0.001$ & $\mathrm{LS} \times \mathrm{CS}, \mathrm{BP}, \mathrm{MSP} ; \mathrm{CS} \times \mathrm{BP}, \mathrm{MSP}$ \\
\hline \multirow[t]{2}{*}{$\mathrm{BE}$} & $\delta^{13} \mathrm{C}$ & 23 & $67.27^{\mathrm{b}}$ & 0.61 & \\
\hline & $\delta^{15} \mathrm{~N}$ & 23 & $5.56^{\mathrm{b}}$ & 0.02 & $\mathrm{CS} \times \mathrm{MSP}$ \\
\hline \multirow[t]{2}{*}{ NI } & $\delta^{13} \mathrm{C}$ & 24 & $0.38^{\mathrm{b}}$ & 0.56 & \\
\hline & $\delta^{15} \mathrm{~N}$ & 24 & $23.26^{\mathrm{b}}$ & $<0.001$ & $\mathrm{MS} \times \mathrm{ESP}$ \\
\hline \multirow[t]{2}{*}{ IC } & $\delta^{13} \mathrm{C}$ & 2,29 & $26.62^{\mathrm{a}}$ & $<0.001$ & $\mathrm{LSP} \times \mathrm{MS}, \mathrm{ESP}$ \\
\hline & $\delta^{15} \mathrm{~N}$ & 2,29 & $53.89^{\mathrm{a}}$ & $<0.001$ & $\mathrm{LSP} \times \mathrm{MS}, \mathrm{ESP} ; \mathrm{ESP} \times \mathrm{MS}$ \\
\hline
\end{tabular}

(b) Inter-locality comparisons within species

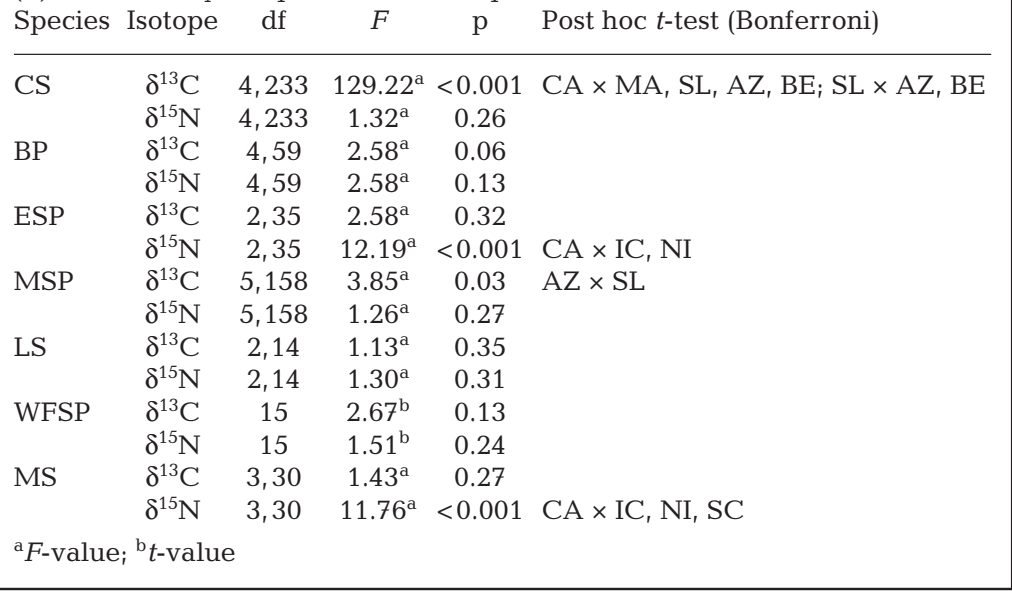

\section{Spatial patterns in stable isotope signatures}

Seabird $\delta^{13} \mathrm{C}$ and $\delta^{15} \mathrm{~N}$ signatures were biogeographically unstructured within the tropical and subtropical NE Atlantic regions. We only found a significant relationship between $\delta^{13} \mathrm{C}$ and latitude for Cory's shearwater. This exception, however, can be explained by the differential exploitation that shearwater populations make of neritic versus oceanic systems rather than by latitudinal isoscapes (Paiva et al. 2010). Shearwaters from the southernmost archipelagos (e.g. Canary Islands) moult the analysed feathers (P1) on the nearby productive upwelling areas on the African continental shelf (Fig. 1), which typically shows more positive $\mathrm{C}$ signatures compared to pelagic systems exploited by shearwaters from the Azores or Madeira. This results in a spurious correlation between $\delta^{13} \mathrm{C}$ signatures and latitude that is not shown in any other species but Cory's shearwater. Isotope results from the rest of the species sampled in the northern and southern Macaronesian archipelagos (e.g. Bulwer's petrels and little shearwaters complex spp. [Cape Verde little shearwaters and Macaronesian shearwaters]) suggest that these species do not usually exploit the African shelf systems, although this region is possibly within the feeding range of most of them. Even though the present study included breeding colonies from Cape Verde to Iceland, differences in stable isotope signatures among localities were only apparent in $\delta^{15} \mathrm{~N}$ signatures between oceanographic provinces from north temperate regions (breeding localities from Northern Ireland, Scotland and Iceland) and those from tropical (Cape Verde) and subtropical regions (breeding localities from the Canary Islands to the Azores) (Fig. 1). In fact, only those species breeding in both north temperate and subtropical regions showed significant inter-colony differences in their $\mathrm{N}$ isotope signatures. This geographic pattern probably explains the larger $\delta^{15} \mathrm{~N}$ signature range (over 9\%) obtained in the present study compared to previous seabird-community studies (Hobson et al. 1994, Thompson et al. 1999).

For the $\mathrm{N}$ isotope signatures, differences between north and mid-north Atlantic populations might be explained by seabird dietary differences or by differences in the baseline isotope signatures between the 2 regions. Manx shearwater populations from the north temperate region mainly feed on clupeids (herring Clupea harengus and sprat Sprattus sprattus) (Brooke 2004). European stormpetrel from the NE Atlantic is thought to prey on a wide variety of resources including pelagic, neritic and inter- 
tidal organisms (e.g. Myctophidae, Gadidae and Cirolanidae, respectively) (D'Elbée \& Hémery 1998). To our knowledge there is no information available about the diet of Manx shearwaters and European storm-petrels in the mid-north Atlantic archipelagos. Consequently, we cannot completely rule out the possible influence of explaining seabird isotope signature differences between these areas. Nevertheless, our results are in line with previous studies on marine isoscapes and chemistry, and therefore support a change in the baseline $\delta^{15} \mathrm{~N}$ level as the most plausible explanation for the enrichment found in the northernmost Atlantic populations. Previous studies found lower $\delta^{15} \mathrm{~N}$ values in plankton, zooplankton and particulate organic matter (POM) in tropical and subtropical regions (including the Macaronesian archipelagos) compared to the north temperate region (Waser et al. 2000, Mino et al. 2002, Montoya et al. 2002, Graham et al. 2009). Different sources of $\mathrm{N}$, such as runoff, atmospheric deposition, subsurface $\mathrm{NO}_{3}{ }^{-}$, and $\mathrm{N}_{2}$ fixation, determine the baseline $\delta^{15} \mathrm{~N}$ of marine biota and could be related to this abrupt change in latitudinal signatures. Overall, in oceanic regions where $\mathrm{N}_{2}$ fixation is the major source of $\mathrm{N}$, i.e. tropical and subtropical North Atlantic regions (Montoya et al. 2002, McClelland et al. 2003), $\delta^{15} \mathrm{~N}$ signatures are depleted in ${ }^{15} \mathrm{~N}$ compared to areas where $\mathrm{NO}_{3}{ }^{-}$transported from deeper layers to the surface has a major role (Montoya et al. 2002), i.e. the North Atlantic temperate region (Donald et al. 2001, Joint et al. 2001, Tyrrell et al. 2003). In addition, our $\delta^{15} \mathrm{~N}$ values for Leach's storm-petrel also support the hypothesis of geographic changes in baseline isotope levels. This species breeds on the north temperate Atlantic but its P1 feather $\delta^{15} \mathrm{~N}$ signatures did not differ from those of Macaronesian breeders. This apparent contradiction is probably explained by the specific moulting pattern and migratory movements of Leach's storm-petrel. It is well known that the wing feathers of this species start moulting after departure from the breeding colonies (Hedd \& Montevecchi 2006). Therefore, isotope values in the P1 feather of this species reflect lower $\mathrm{N}$ isotope signatures from the mid-north Atlantic (including the Macaronesian region) where the storm-petrel is thought to spend the non-breeding period. Furthermore, these conclusions are consistent with previous studies that found a general latitudinal trend in the enriched N signatures of seabirds and marine mammals , from north temperate to Arctic regions (Kelly 2000).

\section{Trophic structure and foraging locations of NE Atlantic seabirds}

Overall, petrels breeding in the NE Atlantic are trophically well-structured. The segregation in spe- cies' isotope signatures suggests that most species exploited specific trophic resources consistent over time and space and with little overlap among species. Petrels and shearwaters are known to be pelagic foragers and their diet is mainly comprised of fish, cephalopods and crustaceans, with different proportions and composition among species (Brooke 2004). While similar isotope values among species or individuals cannot necessarily be interpreted as evidence for similar diets, differences among these values (when no different baseline levels occur) do indicate different feeding patterns and provide evidence for trophic segregation (Hobson et al. 1994).

Procellariiformes from the mid-north Atlantic showed a noticeable overlap in their $\delta^{15} \mathrm{~N}$ signatures, as found in a number of isotopic (Forero et al. 2004) and dietary studies on seabird communities (Diamond 1983). In the present study, most sampled colonies (66\%) were grouped in a narrow range (about $3 \%$ ) of $\delta^{15} \mathrm{~N}$ signatures, which included all mid-north Atlantic breeders except the 2 little shearwater species (Macaronesian shearwater and Cape Verde little shearwater) (Fig. 2). Forero et al. (2004) suggested few dietary alternatives at each trophic level as the cause of overlap in stable $\mathrm{N}$ signatures of seabirds from Patagonia. This is also likely to occur in most petrel populations breeding on mid-north Atlantic archipelagos, since this is an oligotrophic area, and thus, no rich pelagic communities are expected (Longhurst 1998). Alternatively, this result may also be partly explained by higher metabolic rates associated with higher isotope turnovers (protein synthesis and catabolism) in the smaller species (Carleton \& Martínez del Rio 2005, MacAvoy et al. 2006), which may increase their N signatures (Martínez del Rio et al. 2009) and result in an inflated trophic overlap of the whole community. In contrast with $\mathrm{N}, \delta^{13} \mathrm{C}$ signatures provided an axis of variability, and the overlap among species was low. Size differences among species are probably associated with different flight and diving capabilities, which ultimately shape their trophic niches (Shealer 2002). Despite this, we did not recognise obvious general patterns correlating stable isotope signatures with biological traits of the studied species. In some cases, however, feeding locations can explain some differences in the isotope signatures. This is the case for the Cory's shearwaters breeding on the Canary Islands and Selvagens, and Cape Verde shearwaters from Cape Verde islands, which showed significantly greater $\delta^{13} \mathrm{C}$ signatures than any other species and any other Cory's shearwater population breeding on mid-north Atlantic colonies. Since petrels usually breed on isolated archipelagos often far from any continental shelf, $\delta^{13} \mathrm{C}$ differences at intra- or inter-species level are probably related to their capability to reach remote productive 
areas (Shealer 2002). As shown by the GLS devices (Fig. 1), most Cory's shearwaters breeding on the Canary Islands fed along the productive African shelf associated with the Canary Current, resulting in relatively enriched $\delta^{13} \mathrm{C}$ values in their feathers (Magalhães et al. 2008, Navarro \& González-Solís 2009). In contrast, Cory's shearwaters breeding in the Azores fed in pelagic waters and showed depleted $\delta^{13} \mathrm{C}$ values. Probably due to the larger distance to the African coast, Cory's shearwaters breeding on the Selvagens and Cape Verde shearwaters make an intermediate use of the African shelf, resulting in intermediate $\delta^{13} \mathrm{C}$ values.

The lower $\delta^{15} \mathrm{~N}$ signatures of shearwaters breeding in Cape Verde compared to the rest of mid-north Atlantic shearwaters are not explained by biogeographic changes in baseline levels, but likely resulted from a divergence in their trophic niche related to local adaptation to the different prey. For example, the Cape Verde shearwater is about $50 \%$ lighter in mass than Cory's shearwater, and this difference probably limits their potential prey to smaller sizes than in the related Cory's shearwater, resulting in lower N signatures (Badalamenti et al. 2002, Cherel \& Hobson 2005). Alternatively, biogeographic differences between the mid-North Atlantic Subtropical Gyral Province (NAST) and the North Atlantic Gyral Province (NATR) where Cape Verde is situated could explain the differences in $\delta^{15} \mathrm{~N}$ signatures. However, 2 species of petrels also breeding in both areas, the Madeiran storm-petrel and Bulwer's petrel, did not show any shift in their isotope signatures between the 2 oceanic provinces.

Our results also revealed some insights into the poorly known feeding ecology of some petrels and shearwaters from the NE Atlantic, such as the little shearwater complex species and Fea's petrel. Considering that generally, $\delta^{15} \mathrm{~N}$ signatures enrich from $3 \%$ to $5 \%$ for each trophic level across marine food webs (Hobson \& Welch 1992), the isotope signatures of the Macaronesian shearwater and Cape Verde little shearwater reported here suggest that these species feed on a trophic level below the other mid-north Atlantic species. We do not have details on the diet of these 2 species, but a lower trophic level is consistent with previous studies reporting significant lower $\mathrm{Hg}$ levels in Macaronesian shearwater than in Cory's shearwater breeding in the Azores (Monteiro \& Furness 1997). This is because $\mathrm{Hg}$ and trophic level are usually positively correlated, since $\mathrm{Hg}$ biomagnifies through the food chain (Walsh 1990, Bearhop et al. 2000). Diet and movements of Fea's petrel are largely unknown, but its $\delta^{15} \mathrm{~N}$ signature suggests that this species feeds on higher trophic-level prey than Cape Verde shearwater and Cory's shearwater and occasionally exploits the
African shore, since $\delta^{13} \mathrm{C}$ signatures are similar to those found in the Cape Verde shearwater.

Overall, our results highlight the potential of combining isotopic and tracking approaches to reveal a meaningful view on the specific and interspecific trophic ecology of pelagic seabirds as well as to evaluate the influence of baseline isotope signatures when dealing with large-scale and multi-locality studies. However, the present study also exposes the difficulties in interpretation of seabird isotope signatures when their actual diet is poorly known. In summary, the present study suggests baseline isotope signatures are not a relevant source of isotopic variability within marine regions of the NE Atlantic, but they need to be considered when comparing among regions. There were some geographic differences, but unrelated to distance between colonies, oceanographic traits, or geographic coordinates. In contrast, most populations from each species grouped together according to their $\delta^{15} \mathrm{~N}$ and $\delta^{13} \mathrm{C}$ signatures, and interspecific overlap in seabird $\delta^{13} \mathrm{C}$ signatures was relative low, confirming trophic niche as the prime source of isotopic variability across the tropical and subtropical NE Atlantic. Nevertheless, we found a clear enrichment in $\mathrm{N}$ signatures in the north temperate Atlantic compared to the mid-north Atlantic subtropical and tropical regions, which agrees well with previously reported baseline differences in isotope signatures between regions. Therefore, the present study shows that marine isoscapes, although not useful for studying migratory movements of marine organisms at a regional scale, can be a powerful tool to study longdistance migrations between large regions in the NE Atlantic.

Acknowledgements. We thank F. Zino, J. Bried, P. Faria, P. Domínguez, P. Tavares, A. Texeira, P. Lopez., L. F. LópezJurado, J. Nunes, P. Calabuig, F. M. Medina, J. Navarro, Y. Kolbeinsson, T. Jones, H. Swindels, A. D. K. Ramsay, I. A. Sigurdsson, A. M. Maul, R. Magnúsdóttir, C. Rodger, M. A. Peinado, R. Mayor, E. Ventrell, S. Martins, A. Rendall, and the Copeland Bird Observatory team for their help during fieldwork at different stages. Special thanks to X. Ruiz, C. Sanpera, L. Jover, R. De Pedro (Felo), C. Dominguez, Gobierno de Canarias and Cabildo Insular of Gran Canaria, Lanazarote and La Palma for providing us means and support; to our colleagues R. Moreno, R. Ramos, J. Navarro, M. Martinez-Benito, M. López, I. Ortega-Serrano, J. L. Mosquera and F. Ramirez for their professional support; P. Teixidor, P. Rubio and R. Roca from Serveis Científico-Tècnics of the University of Barcelona for their experienced support. J.L.R. and E.G.-D. were supported by a postgraduate grant from the Generalitat de Catalunya, V.N. by a postgraduate grant of the Portuguese Fundaçáo para a Ciênciaea Tecnologia/Foundation for Science and Technology and J.G.-S. by the Ramon y Cajal programme. This work benefited from support by the Ministerio de Ciencia e Innovación (CGL2009-11278/BOS) and Fondos Feder. 


\section{LITERATURE CITED}

Arroyo B, Minguez E, Palomares L, Pinilla J (2004) The timing and pattern of moult of flight feathers of European stormpetrel Hydrobates pelagicus in Atlantic and Mediterranean breeding areas. Ardeola 51:365-373

Badalamenti F, D'Anna G, Pinnegar J, Polunin N (2002) Sizerelated trophodynamic changes in three target fish species recovering from intensive trawling. Mar Biol 3:561-570

Barrett RT, Camphuysen CJ, Anker-Nilssen T, Chardine JW and others (2007) Diet studies of seabirds: a review and recommendations. ICES J Mar Sci 64:1675-1691

Bearhop S, Phillips RA, Thompson DR, Waldron S, Furness RW (2000) Variability in mercury concentrations of great skuas Catharacta skua: the influence of colony, diet and trophic status inferred from stable isotope signatures. Mar Ecol Prog Ser 195:261-268

Bearhop S, Waldron S, Votier SC, Furness RW (2002) Factors that influence assimilation rates and fractionation of nitrogen and carbon stable isotopes in avian blood and feathers. Physiol Biochem Zool 75:451-458

Bolton M, Smith AL, Gómez-Díaz E, Friesen VL and others (2008) Monteiro's storm-petrel Oceanodroma monteiroi: a new species from the Azores. Ibis 150:717-727

Brooke M (2004) Albatrosses and petrels across the world. Oxford University Press, Oxford

Carleton SA, Martínez del Rio C (2005) The effect of coldinduced increased metabolic rate on the rate of ${ }^{13} \mathrm{C}$ and ${ }^{15} \mathrm{~N}$ incorporation in house sparrows (Passer domesticus). Oecologia 144:226-232

Caut S, Guirlet E, Angulo E, Das K, Girondot M (2008) Isotope analysis reveals foraging area dichotomy for Atlantic leatherback turtles. PLoS ONE 3:e1845 doi:10.1371/journal.pone.0001845

Cherel Y, Hobson KA (2005) Stable isotopes, beaks and predators: a new tool to study the trophic ecology of cephalopods, including giant and colossal squids. Proc Biol Sci 272:1601-1607

> Cherel Y, Hobson KA (2007) Geographical variation in carbon stable isotope signatures of marine predators: a tool to investigate their foraging areas in the Southern Ocean. Mar Ecol Prog Ser 329:281-287

Cherel Y, Hobson KA, Guinet C, Vanpe C (2007) Stable isotopes document seasonal changes in trophic niches and winter foraging individual specialization in diving predators from the Southern Ocean. J Anim Ecol 76:826-836

Cramp S, Simmons KEL (1977) The birds of the West Paleartic. Oxford University Press, London

D'Elbée J, Hémery G (1998) Diet and foraging behaviour of the British storm petrel Hydrobates pelagicus in the Bay of Biscay during summer. Ardea 85:1-10

> DeNiro MJ, Epstein S (1978) Influence of diet on the distribution of carbon isotopes in animals. Geochim Cosmochim Acta 42:495-506

> DeNiro MJ, Epstein S (1981) Influence of diet on the distribution of nitrogen isotopes in animals. Geochim Cosmochim Acta 45:341-351

Diamond AW (1983) Feeding overlap in some tropical and temperate seabird communities. Stud Avian Biol 8:24-46

Donald KM, Joint I, Rees AP, Malcom E, Woodward S, Savidge G (2001) Uptake of carbon, nitrogen and phosphorus by phytoplankton along the $20^{\circ} \mathrm{W}$ meridian in the NE Atlantic between $57.5^{\circ} \mathrm{N}$ and $37^{\circ} \mathrm{N}$. Deep-Sea Res II 48:873-897

Forero MG, Bortolotti GR, Hobson KA, Donázar JA, Bertellotti M, Blanco G (2004) High trophic overlap within the seabird community of Argentinean Patagonia: a multi- scale approach. J Anim Ecol 73:789-801

> Forero MG, González-Solís J, Hobson KA, Donázar JA, Bertellotti M, Blanco G, Bortolotti GR (2005) Stable isotopes reveal trophic segregation by sex and age in the southern giant petrel in two different food webs. Mar Ecol Prog Ser 296:107-113

Ginn HB, Melville DS (2000) Moult in birds. The British Trust for Ornithology, Norfolk

Gómez-Díaz E, González-Solís J (2007) Geographic assignment of seabirds to their origin: combining morphologic, genetic, and biogeochemical analyses. Ecol Applic 17: $1484-1498$

González-Solís J, Smyrli M, Militão T, Gremillet D, Tveraa T, Phillips RA, Boulinier T (2011) Combining stable isotope analyses and geolocation to reveal kittiwake migration. Mar Ecol Prog Ser doi:10.3354/meps09233

Graham BS, Koch PL, Newsome SD, McMahon KW, Aurioles D (2009) Using isoscapes to trace the movements and foraging behavior of top predators in oceanic ecosystems. In: West JB, Bowen GJ, Dawson TE, Tu KP (eds) Isoscapes. Understanding movements, pattern, and process on Earth through isotope mapping. Springer, New York, NY, p 299-38

Hedd A, Montevecchi WA (2006) Diet and trophic position of Leach's storm-petrel Oceanodroma leucorhoa during breeding and moult, inferred from stable isotope analysis of feathers. Mar Ecol Prog Ser 322:291-301

Hobson KA (2008) Using endogenous and exogenous markers in bird conservation. Bird Conserv Int 18:S174-S199

> Hobson KA, Clark RG (1992) Assessing avian diets using stable isotopes I: turnover of ${ }^{13} \mathrm{C}$ in tissues. Condor 94 : 181-188

Hobson KA, Welch HE (1992) Determination of trophic relationships within a high Arctic marine food web using $\delta^{13} \mathrm{C}$ and $\delta^{15} \mathrm{~N}$ analysis. Mar Ecol Prog Ser 84:9-18

Hobson KA, Piatt JF, Pitocchelli J (1994) Using stable isotopes to determine seabird trophic relationships. J Anim Ecol 63: 786-798

Jackson DA (1995) Protest: a procrustean randomization test of community environment concordance. Ecoscience 2: 297-303

Jaquemet S, McQuaid C (2008) Stable isotope ratios in Cape gannets around the southern coasts of Africa reveal penetration of biogeographic patterns in oceanic signatures. Estuar Coast Shelf Sci 80:374-380

> Joint I, Wollast R, Chou L, Batten S and others (2001) Pelagic production at the Celtic Sea shelf break. Deep-Sea Res II 48:3049-3081

Kelly JF (2000) Stable isotopes of carbon and nitrogen in the study of avian and mammalian trophic ecology. Can J Zool 78:1-27

> Layman CA, Arrington DA, Montaña CG, Post DM (2007) Can stable isotope ratios provide for community-wide measures of trophic structure? Ecology 88:42-48

> Lesage V, Hamill MO, Kovacs KM (2001) Marine mammals and the community structure of the Estuary and Gulf of St Lawrence, Canada: evidence from stable isotope analysis. Mar Ecol Prog Ser 210:203-221

Longhurst A (1998) Ecological geography of the sea. Academic Press, San Diego, CA

> MacAvoy SE, Arneson LS, Bassett E (2006) Correlaion of metabolism with tissue carbon and nitrogen turnover rate in small mammals. Oecologia 150:190-201

> Magalhães MS, Santos RS, Hamer KC (2008) Dual-foraging of Cory's shearwaters in the Azores: feeding locations, behaviour at sea and implications for food provisioning of chicks. Mar Ecol Prog Ser 359:283-293 
Martínez del Rio C, Wolf N, Carleton SA, Gannes LZ (2009) Isotopic ecology ten years after a call for more laboratory experiments. Biol Rev Camb Philos Soc 84: 91-111

McClelland JW, Holl CM, Montoya JP (2003) Relating low $\delta^{15} \mathrm{~N}$ values of zooplankton to $\mathrm{N}_{2}$-fixation in the tropical North Atlantic: insights provided by stable isotope ratios of amino acids. Deep-Sea Res I 50:849-861

Mino Y, Saino T, Suzuki K, Marañon E (2002) Isotopic composition of suspended particulate nitrogen $\left(\delta^{15} \mathrm{~N}_{\text {sus }}\right)$ in surface waters of the Atlantic Ocean from $50^{\circ} \mathrm{N}$ to $50^{\circ} \mathrm{S}$. Global Biogeochem Cycles 16:1059 doi:10.1029/2001GB 001635

Monteiro LR, Furness RW (1996) Moult of Cory's shearwater during the breeding season. Condor 98:216-221

Monteiro LR, Furness RW (1997) Accelerated increase in mercury contamination in north Atlantic mesopelagic food chains as indicated by time series of seabird feathers. Environ Toxicol Chem 16:2489-2493

Monteiro LR, Ramos JA, Furness RW, Del Nevo AJ (1996) Movements, morphology, breeding, molt, diet and feeding of seabirds in the Azores. Colon Waterbirds 19:82-97

Montoya JP, Carpenter EJ, Capone DG (2002) Nitrogen fixation and nitrogen isotope abundances in zooplankton of the oligotrophic North Atlantic. Limnol Oceanogr 47: $1617-1628$

Navarro J, González-Solís J (2009) Environmental determinants of foraging strategies in Cory's shearwaters Calonectris diomedea. Mar Ecol Prog Ser 378:259-267

Newsome SD, Martinez del Rio C, Bearhop S, Phillips DL (2007) A niche for isotopic ecology. Front Ecol Environ 5: 429-436

Paiva VH, Geraldes P, Ramírez I, Meirinho A, Garthe S, Ramos JA (2010) Foraging plasticity in a pelagic seabird species along a marine productivity gradient. Mar Ecol Prog Ser 398:259-274

Peres-Neto PR, Jackson DA (2001) How well do multivariate data sets match? The advantages of a Procrustean superimposition approach over the Mantel test. Oecologia 129: 169-178

Phillips RA, Silk JRD, Croxall JP, Afanasyev V, Briggs DR (2004) Accuracy of geolocation estimates for flying seabirds. Mar Ecol Prog Ser 266:265-272

Quillfeldt P, McGill R, Furness RW (2005) Diet and foraging

Editorial responsibility: Matthias Seaman,

Oldendorf/Luhe, Germany areas of Southern Ocean seabirds and their prey inferred from stable isotopes: review and case study of the Wilson's storm-petrel. Mar Ecol Prog Ser 295:295-304

- Ramos R, González-Solís J, Croxall JP, Oro D, Ruiz X (2009a) Understanding oceanic migrations with intrinsic biogeochemical markers. PLoS ONE 4:e6236

Ramos R, González-Solís J, Ruiz X (2009b) Linking isotopic and migratory patterns in a pelagic seabird. Oecologia 160:97-105

Ramos R, Militao T, González-Solís J, Ruiz X (2009c) Moulting strategies of a long-distance migratory seabird: the Mediterranean Cory's Shearwater. Ibis 151:151-159

> Rooker JR, Secor DH, De Metrio G, Schloesser R, Block BA, Neilson JD (2008) Natal homing and connectivity in Atlantic bluefin tuna populations. Science 322:742-744

Rubenstein DR, Hobson KA (2004) From birds to butterflies: animal movement patterns and stable isotopes. Trends Ecol Evol 19:256-263

Shealer DA (2002) Foraging behavior and food of seabirds. In: Schreiber EA, Burger J (eds) Biology of marine birds. CRC Press, Boca Raton, FL, p 137-177

> Spear LB, Ainley DG (2007) Storm-petrels of the eastern Pacific Ocean: species assembly and diversity along marine habitat gradients. Ornithol Monogr 62:1-77

> Thompson DR, Lilliendahl K, Solmundsson J, Furness RW, Waldron S, Phillips RA (1999) Trophic relationships among six species of Icelandic seabirds as determined through stable isotope analysis. Condor 101:898-903

> Tyrrell T, Marañon E, Poulton A, Bowie AR, Harbour DS, Woodward EMS (2003) Large-scale latitudinal distribution of Trichodesmium spp. in the Atlantic Ocean. J Plankton Res 25:405-416

Walsh PM (1990) The use of seabirds as monitors of heavy metals in the marine environment. In: Furness RW, Rainbow PS (eds) Heavy metals in the marine environment. CRC Press, Boca Raton, FL, p 183-204

Waser NAD, Harrison WG, Head EJH, Nielsen B, Lutz VA, Calvert SE (2000) Geographic variations in the nitrogen isotope composition of surface particulate nitrogen and new production across the North Atlantic Ocean. DeepSea Res I 47:1207-1226

West JB, Bowen GJ, Cerling TE, Ehleringer JR (2006) Stable isotopes as one of nature's ecological recorders. Trends Ecol Evol 21:408-414

Submitted: August 28, 2010; Accepted: May 16, 2011

Proofs received from author(s): July 12, 2011 